Portland State University

PDXScholar

Engineering and Technology Management

Faculty Publications and Presentations

8-2-2015

\title{
Exploring the Adoption and Use of the Smartphone Technology in Emerging Regions: A Literature Review and Hypotheses Development
}

Fahad Aldhaban

Portland State University

Tugrul Unsal Daim

Portland State University, tugrul@etm.pdx.edu

Robert R. Harmon

Portland State University, harmonr@pdx.edu

Follow this and additional works at: https://pdxscholar.library.pdx.edu/etm_fac

Part of the Operations Research, Systems Engineering and Industrial Engineering Commons Let us know how access to this document benefits you.

\section{Citation Details}

Rahman, N., \& Aldhaban, F. (2015, August). Assessing the effectiveness of big data initiatives. In Management of Engineering and Technology (PICMET), 2015 Portland International Conference on (pp. 478-484). IEEE.

This Article is brought to you for free and open access. It has been accepted for inclusion in Engineering and Technology Management Faculty Publications and Presentations by an authorized administrator of PDXScholar. Please contact us if we can make this document more accessible: pdxscholar@pdx.edu. 


\title{
Exploring the Adoption and Use of the Smartphone Technology in Emerging Regions: A Literature Review and Hypotheses Development
}

\author{
Fahad Aldhaban, Tugrul U. Daim, Robert Harmon \\ Portland State University, Portland, OR - USA
}

\begin{abstract}
Users' acceptance of a new information technology (IT) is a determining factor of its market success. A solid understanding of the users' adoption process and use behavior enables a more robust definition of user requirements and better market alignment. This is especially important in markets characterized by rapid technological change such as smartphones. The Technology Acceptance Model (TAM) is often used to assess the factors affecting adoption of new technologies. However, TAM models often omit the role of important variables such as human and social factors in the adoption process. In developing markets such as China, cultural and social influences significantly impact the adoption and use of smartphones and related technologies. Similarly, Saudi Arabia has unique cultural and social contexts that may influence the adoption and use of smartphone technology, but as yet have not been studied in a comprehensive manner. Accordingly, the purpose of this paper is to develop the foundation for a theoretical research model based on the Unified Theory of Acceptance and Use of Technology (UTAUT). The case of smartphone adoption and use in Saudi Arabia will be its focus.
\end{abstract}

\section{INTRODUCTION}

\section{A. Users' adoption and use of the Smartphone technology}

Studying and understanding users' adoption and use of new technologies is very critical for both researchers and practitioners [1]. Studying the key factors that influence adoption of a new Information technology helps to explain and predict users' attitude toward adopting or rejecting that new technology. Users' acceptance of a new information technology (IT) is considered to be a key determinant of its success and their lack of acceptance is considered to be an obstacle of its success [2]. Moreover, understanding users' adoption and use of new IT plays an important role in determining users' needs and reducing business risk especially with rapid changes in the IT such as Smartphone technology. [3]. Smartphone technology is defined as "a hand-held computer capable of multiple functions in addition to placing calls" [4]. Also, as "a mobile phone offering advanced capabilities, often with PC-like functionality (PC mobile handset convergence)" [5]. Smartphone technology is a relatively new technology that is rapidly evolving and gradually impacting consumers' behavior, their daily activities, their social activities, the mobile industry, business activities, marketing, education, healthcare and more [6-8]. Smartphone technology offers the potential as a means to improve efficiency, productivity, reduce cost, improve users' satisfactions and enhance their experience in a number of related industries including mobile industry, healthcare, financial, ecommerce, education, entertainment, tourism and more [9-11]. Competition among many manufacturers, developers and providers in the Smartphone industry is still very intense. Many device manufacturers such as Apple, Samsung and LG are competing to gain more market share and obtain more customers. In manufacturing the operating system for the Smartphone the global competition is still fierce among many competitors including Apple, Android, Microsoft, Symbian, Bada, and RIM [12, 13]. Smartphone users are considered to be an important key factor to continue a successful growth for the Smartphone technology and all of its stakeholders $[14,15]$. Consequently, evaluating and better understanding the key factors that influence users' adoption and use of Smartphone technology has become more important to all stakeholders to improve related products/services, and to meet consumers' expectations [14, 16]. Scholars from different fields and interests agree on the importance of Smartphone technology as critical evolutions in the information technology domain [17]. A number of research studies have been conducted to explore users' adoption and use of the Smartphone technology. However, most of the existing empirical research focused only on a limited number of factors that influence users' adoption and use of smartphones such as the fun aspect of using smartphones [17], or the effect of the enjoyment aspect of smartphones [18]. Moreover, a number of empirical research studied smartphones as if it were a tool to be used in executing a specific task such as using the Smartphone in the healthcare sector [19]. Other researchers focused their research on a specific profession such studying adoption of smartphones among doctors and nurses [20,21], studying the adoption of smartphones among employees in delivery services [22] or studying the adoption and use of smartphones among college students [23]. Studying only one or few factors that influence users' adoption of Smartphone technology will result in neglecting other important factors and making it harder to gain a complete perspective. It is more appropriate to examine and compare all related characteristics within the same research in a holistic and comprehensive manner [24]. In a number of studies, scholars pointed out the important role of cultural and social factors and their influence on the adoption and use of new information technologies [25-29]. Saudi Arabia is a developing country and it has different social and cultural contexts can be characterized as a society that is relatively collectivist in nature as individuals have closer ties and high influence among and between them [25]. In a number of empirical studies, scholars studied the adoption and use of a number of technologies in Saudi Arabia, including the adoption of mobile internet [6], adoption and use of e- 


\section{Proceedings of PICMET '15: Management of the Technology Age}

services [30], and acceptance and use Information Technology [25]. Their results showed that a number of factors, namely social influences, facilitating conditions and language showed significant relationships with users' adoption and use IT in Saudi Arabia. In emerging regions, specifically Saudi Arabia, little or no effort has been made to study and explore the key factors that influence users to adopt and use the Smartphone technology. With this environment, understanding users' intention to adopt and use the Smartphone technology has become a very important factor that needs to be better understood, especially when creating and providing mobile products, services, contents, applications and its related products [31]. However, there has been very little effort to empirically study the factors that influence the adoption and use of the Smartphone technology in Saudi Arabia in a holistic manner.

\section{B. Adoption and use of Smartphone and its related technologies in emerging regions}

Arpaci et al. [32] investigated the impacts of cultural differences on Smartphone adoption by organizations in Canada and Turkey. Their finding showed that cultural differences have a significant influence on adoption behavior. Their results indicated that there are significant differences in factors that influence the adoption of Smartphone between countries [32]. A number of empirical research studies were conducted to study the key factors that influence users' adoption and use of the Smartphone and its related technologies in China, also an emerging region. In most of these studies, cultural and social influences showed a significant relationship with users' adoption and use the Smartphone and its related technologies:

Pan et al. [33] empirically investigated the key factors that influence the adoption of the Smartphone among college students in China. Their results showed that social influence has a significant and positive influence on users' adoption of the Smartphone [33]. Ling and Yuan [34] utilized the Theory of Reasoned Action (TRA) to empirically study the factors that influence users adoption and use the Smartphone in China and found that subjective norms were among the significant factors that have positive effects the use of the Smartphone [34]. Dai and Palvia [14] conducted a cross cultural empirical research to study the factors that influence users' adoption of mobile commerce in the United States and China. Their results showed a number of significant differences among factors that influence users' adoption of mobile commerce which include that subjective norms showed more influence on users' adoption in China then in the United States [14]. Hill et al. [35] stated that "As most technology is designed and produced in developed countries, it is culturally-biased in favor of those developed countries' social and cultural systems". Also, they indicated that Arabic different culture and society have an influence on how the new IT is accepted, viewed and utilized among users in the Arab world [35]. Saudi Arabia is a country that is witnessing rapid development and has different cultural and social contexts which may influence users' adoption and use of the Smartphone and its related technologies. Moreover, it has been indicated that there is a need for more empirical research to identify the key factors that influence users' behavioral intention to adopt and use the Smartphone technology in a comprehensive manner [36-38]. Also, a number of scholars mentioned the lack of research that investigates the key factors that influence the acceptance and use of Smartphone technology in Saudi Arabia [39, 40, 11, 41]. Moreover, there is a lack of empirical research regarding the key factors that influence general users' intention to adopt and use the Smartphone in a holistic and comprehensive approach.

\section{Research related to Smartphone technology in Saudi Arabia}

Arabic is the main language of Saudi Arabia's population. Numerous scholars mentioned that the English language was one of the factors that the adoption and use of the internet and e-services in Saudi Arabia [30]. The majority of IT services' contents are designed with English version interfaces and intended mostly for English speaking consumers [30]. In many studies, scholars pointed out the important role of the cultural factors and their influence on the adoption and use of new information technologies [2529]. Saudi Arabia has different cultural contexts. Saudi Arabia is characterized as society that is more collectivist in nature in which individuals have closer ties and high influence among them [25]. Gahtani et al. [25] studied the effects of the cultural aspects on the acceptance and use of IT in Saudi Arabia. In their research they found that subjective norms positively influence users' intention to use IT in Saudi Arabia.

Numerous studies have been conducted in subjects related to the Smartphone technology in Saudi Arabia. Alwahaishi and Snasel studied the factors that influence users to adopt mobile internet in Saudi Arabia [6]. They indicated that smartphones represented about 12 percent of the total handset traffic worldwide. They found that performance expectancy and perceived playfulness are the strongest influential factors on users' behavioral intention to use mobile internet. Seliaman and Al-Turki [41] studied mobile learning in Saudi Arabia. They mentioned the lack of published research that studied adoption of mobile technology in Saudi Arabia. Saddik et al. [11] studied the adoption of PDA and the Smartphone among physicians and dentist in King Saud Medical Hospitals in Saudi Arabia. Also, they mentioned the need for research to study the adoption of the Smartphone which may help to increase users' productivity and decrease costs especially in the healthcare sector. Numerous scholars mentioned the lack of research that investigates and explores the key factors that influence the acceptance and use of Smartphone technology in Saudi Arabia in a holistic manner [39, 40, 11, 41]. Therefore, this research is aiming to develop a theoretical research model to be utilized to identify and 
explore the key factors that influence general users' adoption and use of the Smartphone technology in Saudi Arabia.

\section{LITERATURE REVIEW}

\section{A. Relevant Theories Used to Study the Adoption and Use of (IT)}

Scholars interest in studying and understanding users' adoption and use of new IT in both the organizations level and in the individual's level have been evolving since number of decades ago [42]. With evolvement of the IT, a number of theories have been developed and modified to better study and understand users' acceptance and use of new IT. Dillon and Morris [43] defined users' acceptance as "the demonstrable willingness within users group to employ information technology for the tasks it is designed to support". As information technologies evolve and the nature of each technology changes, theories of IT adoption evolves as well. In attempt to better understand, predict and explain users' adoption and use of new technologies in both the organizational' level and in the individuals' level, a number of theoretical models have been introduced, developed and tested including the following:

Theory of Reasoned Action (TRA), developed by Fishbein and Ajzen in 1975, it explains users' intention to comet a behaviors that is influenced by both attitude and subjective norm. Attitude was defined as "an individual positive and negative attitude towards performing the target behaviors" [44]. Subjective norm is defined as "the person's perception that most people who are important to him think he should or should not perform the behavior on question" [43]. TRA suggested that users' attitude and subjective norm predicts behavioral intention which intern predict users' behavior [43]. TRA could be one of the most influential theoretical models to predict and explain users' behavior [45]. A number of scholars utilized TRA to developed number theoretical models that are well established and widely utilized to explain users' behavior intention to adopt information technology including the Technology Acceptance Model (TAM), the Theory of Planned Behaviors (TPB) and the Unified Theory of Acceptance and Use of Technology (UTAUT) [46, 47, 45]. Technology acceptance model (TAM) introduced by Davis in 1989, TAM model was adopted from TRA Model. TAM model is a very popular model among researchers and it is the most widely used and cited theoretical model $[2,48,49]$. TAM model introduced two variables namely; perceived ease of use and perceived usefulness, which mostly can explain and determine users' attitude and behaviors toward accepting new technology [50, 51]. Perceived ease of use is defined as "the degree to which a person believes that using a particular system would be free of effort" and usefulness is identified as "the degree to which a person believes that using a particular system would enhance his or her job performance." [52]. TAM model is one of the most widely used models to study and explain users' intention to use Smartphone technology and its retaliated technology. Kang et al. [36] used TAM model to analyze factors affecting adoption of Smartphone. Verkasalo, et al. [53] used TAM model to study users' intention to use specific Smartphone' applications. Kim [54] extended TAM model to study users' intention to adopt mobile wireless technology (MWT) - Smartphone. Chen et al. [22] combined IDT and TAM model to explain the users' adoption of Smartphone. However, TAM model is able to explain only about $40 \%$ of variances of technology acceptance [45]. Moreover, a number of scholars have specified a number of limitations in the TAM model and highlighted the need for adding more variables to the model especially related to human and social factors [55]. Theory of planned behaviors (TPB) was introduced in 1991 by Ajzen, and it was a derivation of TAR. Psychology is the origin field for the TPB theory and it is used to explain users' behavior. TPB theory states that subjective norms, attitude and perceived behavioral control determine behavior intention and therefore behavior [46, 2, 56]. Theory of planned behaviors was used to develop a number of IT theory including the Unified Theory of Acceptance and Use of Technology. A number of scholars studied the TPB and suggests extending the TPB model as a way that will improve the outcome and help to obtain better explanation of the relationship of intentions to behavior [57]. Goodhue and R. L. Thompson [58] develeped the Technology Task Fit (TTF) to explain the impact of information technology on users' performance. TTF was defined as "the degree to which a technology assists an individual in performing his or her portfolio of tasks" [58]. TTF models have five main constructs namely: Task Characteristics, Technology Characteristics, task technology fit, Performance and Utilization [58]. TTF model suggests that Task Characteristics, Technology Characteristics, together predict the Task Technology Fit constructs, which in turn predict individual's Performance and Utilization [58]. Goodhue and Thompson [58] suggested that, TTF could be used as an effective tool to evaluate if an information system is meeting users' needs. Moreover, they mentioned that, when an information system has correspondence between its functionality and users' task requirements it positively affects their performance [58]. Task Technology Fit constructs found to have a positive and significant relationship with individual's Performance [58].

Venkatesh [45] introduced the Unified Theory of Acceptance and Use of Technology (UTAUT) which is based on the integration of TRA, TAM, TPB, motivational Model (MM), model of PC Utilization (MPCU) IDT and Social Cognitive Theory (SCT). UTAUT is been used to study and explain users' acceptance of information technology in many fields. UTAUT consists of four main constructs namely: performance expectancy, effort expectancy, social influence and facilitating conditions that can explain and predict individual's behavioral intention and use behavior [45] Performance expectancy is defined as the degree to which an individual believes that using a Smartphone will help him or her to attain benefits in their overall performance. Effort 
2015 Proceedings of PICMET '15: Management of the Technology Age

TABLE 1: SUMMARY OF RELEVANT IT THEORETICAL MODELS

\begin{tabular}{|c|c|c|c|c|c|}
\hline Theory/model & $\begin{array}{l}\text { Main } \\
\text { Dependent } \\
\text { Constructs }\end{array}$ & $\begin{array}{l}\text { Main } \\
\text { Independent } \\
\text { Constructs }\end{array}$ & Origin & $\begin{array}{l}\text { Originating } \\
\text { Area }\end{array}$ & Introduced \\
\hline $\begin{array}{l}\text { Theory of } \\
\text { Reasoned Action } \\
\text { (TRA) }\end{array}$ & $\begin{array}{l}\text { Behavioral } \\
\text { Intention, } \\
\text { Behavior }\end{array}$ & $\begin{array}{l}\text { Attitude Toward } \\
\text { Behavior, } \\
\text { Subjective } \\
\text { Norm, }\end{array}$ & & $\begin{array}{l}\text { Social } \\
\text { psychology }\end{array}$ & $\begin{array}{l}\text { Fishbein and } \\
\text { Ajzen (1975) }\end{array}$ \\
\hline $\begin{array}{l}\text { Technology } \\
\text { Acceptance } \\
\text { Model (TAM) }\end{array}$ & $\begin{array}{l}\text { Behavioral } \\
\text { Intention to } \\
\text { Use, } \\
\text { System Usage }\end{array}$ & $\begin{array}{l}\text { Perceived } \\
\text { Usefulness, } \\
\text { Perceived Ease of } \\
\text { Use }\end{array}$ & $\begin{array}{l}\text { adopted from } \\
\text { TRA }\end{array}$ & $\begin{array}{l}\text { Information } \\
\text { Systems }\end{array}$ & Davis (1989) \\
\hline $\begin{array}{l}\text { Theory of } \\
\text { Planned } \\
\text { Behavior (TPB) }\end{array}$ & $\begin{array}{l}\text { Behavioral } \\
\text { Intention, } \\
\text { Behavior }\end{array}$ & $\begin{array}{l}\text { Attitude Toward } \\
\text { Behavior, } \\
\text { Subjective } \\
\text { Norm, Perceived } \\
\text { Behavioral Control }\end{array}$ & $\begin{array}{l}\text { derivation of } \\
\text { TRA }\end{array}$ & $\begin{array}{l}\text { Social } \\
\text { psychology }\end{array}$ & Ajzen (1991) \\
\hline $\begin{array}{l}\text { Unified Theory } \\
\text { of Acceptance } \\
\text { and Use of } \\
\text { Technology } \\
\text { (UTAUT) }\end{array}$ & $\begin{array}{l}\text { Behavioral } \\
\text { intention, } \\
\text { Usage } \\
\text { behavior }\end{array}$ & $\begin{array}{l}\text { Performance } \\
\text { expectancy, } \\
\text { Effort expectancy, } \\
\text { Social } \\
\text { influence, } \\
\text { Facilitating } \\
\text { conditions, }\end{array}$ & $\begin{array}{l}\text { Adopted from: } \\
\text { TRA, TAM, } \\
\text { TPB, } \\
\text { motivational } \\
\text { Model (MM), } \\
\text { model of PC } \\
\text { Utilization } \\
\text { (MPCU) IDT } \\
\text { and Social } \\
\text { Cognitive } \\
\text { Theory (SCT). }\end{array}$ & $\begin{array}{l}\text { Information } \\
\text { Systems }\end{array}$ & $\begin{array}{l}\text { Venkatesh et } \\
\text { al. (2003) }\end{array}$ \\
\hline $\begin{array}{l}\text { Task-technology } \\
\text { fit (TTF) }\end{array}$ & Performance & $\begin{array}{l}\text { Task } \\
\text { Characteristics } \\
\text { Technology } \\
\text { Characteristics } \\
\text { Task Technology } \\
\text { Fit, Utilization. }\end{array}$ & & $\begin{array}{l}\text { Information } \\
\text { Systems }\end{array}$ & $\begin{array}{l}\text { Goodhue and } \\
\text { Thompson, } \\
\text { (1995) }\end{array}$ \\
\hline
\end{tabular}

expectancy is defined as the degree of ease associated with the use of the Smartphone. Social influence is defined as the extent to which an individual perceives that important others to believe he or she should use a Smartphone. Facilitating conditions is defined as "the degree to which an individual believes that technical and infrastructure supports are available to support the use of Smartphone. UTAUT suggest that, performance expectancy, effort expectancy, and social influence constructs can predict behavior intention construct which in return predict the use behavior construct. Today's information technologies such as the Smartphone and its related technologies are developing in fast rate. Thus a great effort has been made to develop more reliable and comprehensive theoretical model that can explain and predict users' adoption and use of IT. It is observed from this literature review that theoretical models have been developed to gain better results and account for the changes in technologies and users' behaviors. As shown in table 1 below many of the newer IT theoretical models such as UTAUT are based on derivations from older models and consist of more and improved constructs which make them more mature and more suitable to study the newer technologies such as the Smartphone and its related technologies. Table 1 lists the relevant IT theoretical IT models.

\section{B. Research Related to the Adoption and Use of Smartphone}

Smartphone technology evolves even more quickly than other types of IT, and its popularity has gained attention among scholars in both academia and industry. Publication of research in subjects related to adoption and use of Smartphone technology is increasing continuously which indicates the importance of studying and understanding adoption and use of Smartphone technology among scholars in various fields [59]. Significant effort has been made by scholars with different interests, using different approaches, methods, and theories to study various aspects related to Smartphone technology to explore and better understand users' adoption and use of this technology. Kang et al. [36] applied the TAM model in their research to analyze factors affecting adoption of Smartphone technology. Their research model included five derived primary function attributes (wireless internet, design, multimedia, application, and after service). They indicated that most research on adoption of Smartphone assumed that the Smartphone is a tool used for specific purpose such as medical usage. Also, they emphasized the need for studying adoption of Smartphone in a holistic approach that covers general consumers and usage. Verkasalo, et al. [53] studied adoption of Smartphone' applications using TAM model to understand users' intention to use specific Smartphone's applications including internet access, mapping services, and games. Their research model included the following variables: behavioral control, technical barriers, social norms, perceived enjoyment. They highlighted the needs for further research that investigate the impacts of social norms factors on adoption of Smartphone adoptions. Combining IT theoretical models was an approach that numerous researchers used in an attempt to more comprehensively study and predict adoption of Smartphone technology. Chen et al. [22] combined Innovation Diffusion Theory (IDT) and TAM models to study and explain the adoption of Smartphone. Their study was limited to the logistics industry, specifically on delivery employees in a delivery service company. Their research model tested the effects of self-efficacy, compatibility, observable, testability, task, individual, and organization environment factors on adoption of Smartphones. Choudrie et al. [60] combined a 
number of theories namely: Unified Theory of Acceptance and Use of Technology (UTAUT), the Diffusion of Innovations theory (DoI), and TAM to study the adoption and use of the Smartphone by older adults in the United Kingdom.

Huang et al. [61] believes that a Smartphone could become a suitable substitute of traditional computer, yet the performance of Smartphone applications is poorly understood. So, they used systematic methodology to study and to better understand factors that impact users' perceived performance of some Smartphone applications. Studying adoption and use of Smartphone technology by focusing on just one brand of Smartphone devices such as the Apple iPhone was an approach that a number of scholars used in their research $[62,63]$. Based on Ganesh and Kumar's work, Chris Maloney [63] developed a framework to explore the learning effects' influence on the rate of adoption in the market to better explain the impact of the learning effect on adoption rate of the iPhone [63]. Also, Kim and Song [62] investigated the adoption and use of Blueberry Smartphone.

Focusing on or studying only a single factor or aspect that impacts users' adoption and use of Smartphone technology was an approach that a number of scholars used. Chtourou and Souiden [17] used the TAM model to study the effect of one factor, namely the entertainment of using the Smartphone in browsing the internet. They found that pleasure is an important factor that affects user attitudes toward the use of the mobile internet. Moreover, they emphasized the importance of including emotional motivations when studying users' adoption of innovation. Their study was limited to the use of mobile internet and they suggested a further study to modify and include other products/services. Also, Song and Han [18] used UTAUT to study the importance of the enjoyment aspect of the users' adoption of new technology in mobile services. They examined the relationship between content quality and perceived enjoyment. Also they examined the effect of social influence and the quality system on behavior intention of the user. They emphasized on the importance of the enjoyment aspect on mobile services acceptance. In another study, using survey and clusters analysis, scholars explored the usages and adoption rates of Smartphone multimedia in four clustered users; youngster, female, male and the older users [64]. Also, Shin et al. [65] indicated that Smartphone technology is not yet ubiquitous in the educational sector. They also mentioned the limitations of academic research on Smartphone technology as a learning tool. They examined factors that influence users' intentions to use Smartphone as a ubiquitous learning tool. In their research model, they modified unified theory of acceptance and use technology (UTAUT) and they used constructs from expectation confirmation theory (ECT).Their research focused on ten universities where a survey was distributed to faculty, staff and students. They highlighted that a limited aspects of users experience with Smartphone was reflected on, also they suggested that including more factors in further research would enable better understanding of Smartphone user' behaviors.

Adoption of Smartphone technology is a popular subject among researchers in the healthcare industry. Researchers in a number of articles looked at Smartphone technology as a very useful tool that could be utilized to improve performance and quality of work in that environment. Park and Chen [20] used the TAM model to study the adoption of Smartphone technology in the healthcare sector and they investigated the factors that affect the adoption of Smartphone technology among doctors and nurses. Their research model includes the following factors: compatibility, observability, trialability, and task individual organization environment factors. They indicated the need for further research to investigate the adoption of Smartphone technology. Also, Putzer and Park [21] investigated factors that affect individuals' decision in healthcare profession to adopt Smartphone. Their research model incorporated aspects of the TAM model and DOI theory. The effects compatibility, observability, job relevance, personal demographics, personal experience internal environment, and external environment on adoption of Smartphone technology among nurses were investigated. The study focused on nurses in two community hospitals and it included organizational factors that may affect adoption of Smartphone in healthcare environments.

Many scholars looked at the adoption of Smartphone with regards to their roles in finance, marketing and business activities. Smartphone technology can be utilized to improve company to customer relationships. Marketing applications are still in the early stage of adoptions [10]. With the advancement of Smartphone technology and its ability to handle data and commercial transactions, banks have become aware of Smartphone advancements and popularity among consumers and started to act accordingly. In number of articles scholars tried to study and understand consumers' adoption of mobile banking and related issues. Many banks started to have mobile banking options for their customers to insure better future position as the popularity of Smartphone increase. Zhou et al. [66] integrated the task technology fit (TTF) model and the unified theory and use technology (UTAUT) to study the adoption of mobile banking. They analyzed the following factors: task characteristics, technology characteristic, performance expectancy, effort expectancy, social influence, and facilitating conditions to determine users' adoption of mobile banking. They highlighted the importance of the task technology fit where a new technology has to fulfill users' task requirements in order to be adopted by that user. Koenig-Lewis et al. [67] examined adoption of mobile banking using the TAM model. They investigated the influence of trust, credibility, compatibility, perceived risk and cost factors on users' behavioral intention to adopt mobile banking services. Their study targeted group of individuals in Germany who are mostly going to adopt mobile banking. Their research indicated that trust and risk factors can be more or less 
influential depending on other factors such as technological infrastructure that was not included in their study. Moreover, in a qualitative approach Mallat [68] used focus group interviews to explore factors that influence adoption of mobile payments. He studied the following adoption factors: relative advantage, compatibility, complexity, costs, network externalities, trust, perceived security and risk. Bauer et al. [69] highlighted the lack of academics research that allowed for better understanding of mobile marketing as new trend in marketing. They used The Theory of Reasoned Action (TRA) to investigate factors effecting users to adopt mobile marketing. Tao and Zhou [70] used the UTAUT model to examine key factors that influence users' acceptance and use of mobile commerce. In their research model they examine the influence of the following factors: contextual offering' performance expectancy, effort expectancy, social influence and facilitating conditions on the users' intention to use m- commerce. Also, Wu and Wang in an empirical study [71] utilized the TAM model to investigate factors that determine users' acceptance of mobile commerce, their research model examines compatibility, perceived risk and cost. Scholars discussed and explored mobile ecosystem from a business perspective [72]. Also, scholars explained the ecosystem of Smartphone and analyzed Smartphone' operating systems market under a uniform framework [73]. Finally, scholars explored how Smartphone influence work processes and attitude toward technology as it can boost performance, also how adoption of Smartphone technology improved collaboration between the workforce and their organization [74].

Based on the literature review conducted, taxonomy has been developed that includes the research topic, theory or model used, variables identified in the research and a summary of the results as shown in table 2 below.

TABLE: 2 SUMMARY OF EMPIRICAL RESEARCH RELATED TO THE ADOPTION OF SMARTPHONE TECHNOLOGY

\begin{tabular}{|c|c|c|c|c|}
\hline Research topic & $\begin{array}{c}\text { Theory - } \\
\text { Model }\end{array}$ & Independent Variables & $\begin{array}{c}\text { Dependent } \\
\text { Variables }\end{array}$ & Results \\
\hline $\begin{array}{l}\text { Identify the important factors that } \\
\text { influence users' intention to adopt } \\
\text { mobile Value Add Services (VAS) } \\
\text { [75] }\end{array}$ & $\begin{array}{l}\text { Conjoint } \\
\text { analysis using } \\
\text { SPSS }\end{array}$ & $\begin{array}{l}\text { Personalization } \\
\text { Content } \\
\text { Cost } \\
\text { Screen size } \\
\text { Service speed } \\
\end{array}$ & Preference & $\begin{array}{l}\text { Their results include that: speed, cost and } \\
\text { content are the most important factors to } \\
\text { overall mobile service preference. }\end{array}$ \\
\hline $\begin{array}{l}\text { To investigated the key factors that } \\
\text { influence the adoption of the } \\
\text { Smartphone among college student in } \\
\text { China [33] }\end{array}$ & TAM & $\begin{array}{l}\text { Self-efficacy } \\
\text { Attitude to use } \\
\text { Perceived ease of use } \\
\text { Social influence } \\
\text { Perceived usefulness } \\
\text { Entertainment utility } \\
\text { Compatibility } \\
\end{array}$ & $\begin{array}{l}\text { Behavioral } \\
\text { intention }\end{array}$ & $\begin{array}{l}\text { Their results indicated that: social } \\
\text { influence, entertainment utility, } \\
\text { compatibility all had a significant positive } \\
\text { impact on } \\
\text { user's perceived usefulness of smartphone }\end{array}$ \\
\hline $\begin{array}{l}\text { To studied the adoption and use of the } \\
\text { Smartphone by older adults in the } \\
\text { United Kingdom [60] }\end{array}$ & $\begin{array}{l}\text { TAM, UTAUT, } \\
\text { DOI }\end{array}$ & $\begin{array}{l}\text { Observability, Compatibility, } \\
\text { Social influence, Facilitating } \\
\text { conditions, } \\
\text { Effort expectancy Enjoyment }\end{array}$ & $\begin{array}{l}\text { Behavioral } \\
\text { intention and } \\
\text { use behavior }\end{array}$ & $\begin{array}{l}\text { Their results include that: observability, } \\
\text { compatibility, social influence, facilitating } \\
\text { conditions, effort expectancy and } \\
\text { enjoyment are important to the adoption } \\
\text { and use of Smartphone among older adults } \\
\text { in UK. }\end{array}$ \\
\hline To study users' behavioral intention & TAM & Perceived cost saving, Company's & Actual use & Finding include that : PU was significantly \\
\hline
\end{tabular}


2015 Proceedings of PICMET '15: Management of the Technology Age

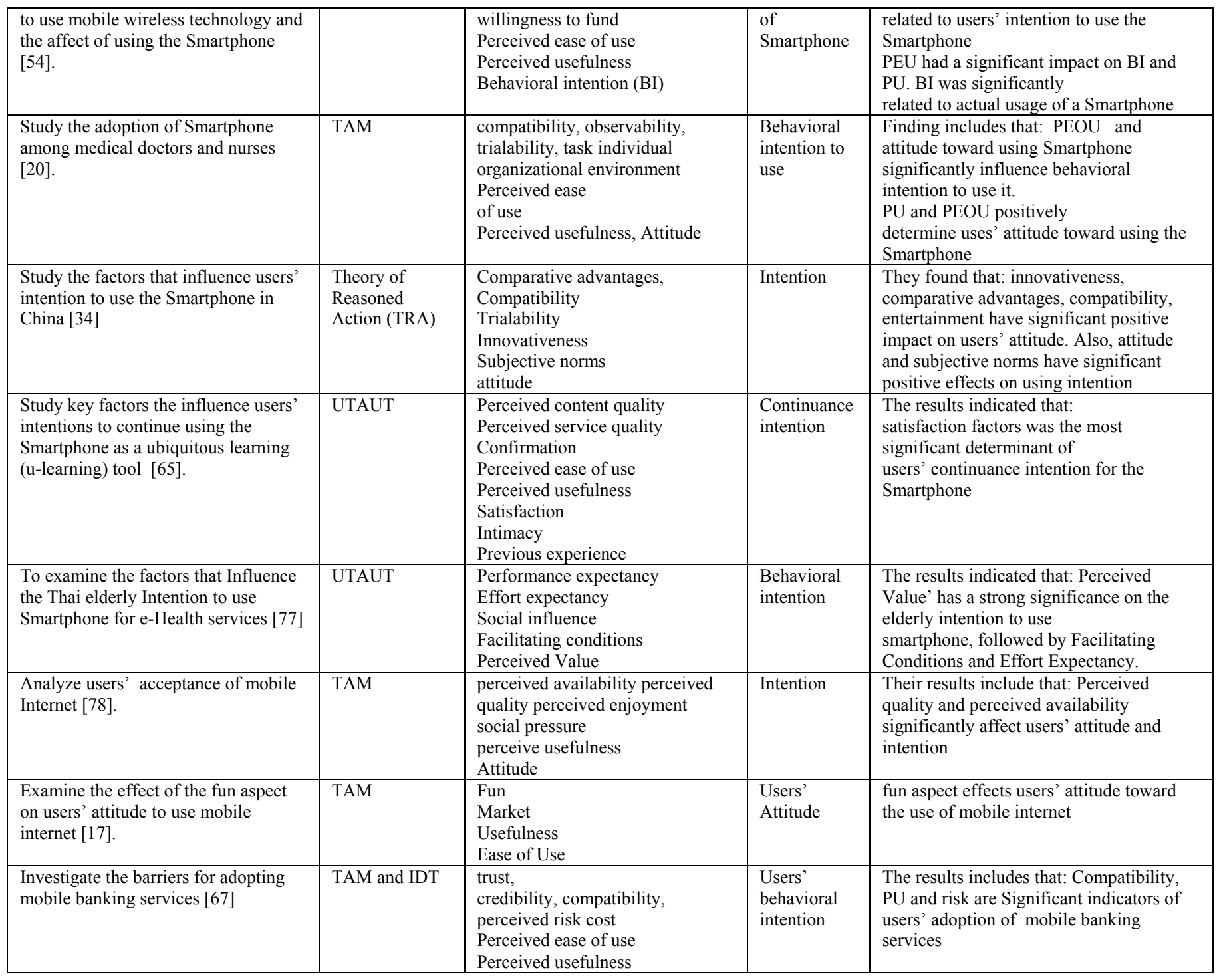

According to Sekaran [79] identifying factors that have been determined as important in previous research accompanied with rational relationships and connections can be logically conceptualized to form the basis of a research theoretical framework or model. Thus, factors that have been determined in previous research as important and related to the adoption and use of Smartphone and its related technologies have been logically conceptualized and classified under six main constructs as show in figure 1 below. The main factors identified in the taxonomy are based on theoretical basis and have been identified to have a relationships with the users' intention to adopt and use new IT such as Smartphone technology [80, 45]. For instance, a number of factors are classified under the technology characteristics and performance because they were associated with it either directly or through other factors such as perceived usefulness, and relative advantage [68], which may improve users' performance when using the Smartphone technology [45]. These factors that are classified under technology characteristics and performance include: perceived usefulness $[22,81,36,67,78,18,45]$, Job relevancies [76, 78], relative advantage [68], perceived ubiquity $[82,76]$, perceived reachability [76], mobility [83], accuracy [82], controllability [68], security [68], perceived availability [81, 78], perceived quality [78], content [75, 83], service speeds [83], multimedia [36], applications [36], wireless Internet [36]. The above mentioned factors are related to technology characteristics and performance therefore they are classified under it in this developed taxonomy. To obtain only the factors that are most related to the adoption and use of the smartphone, further evaluation, selection and validation have been conducted using brainstorming session, focus group session and individual interviews. 


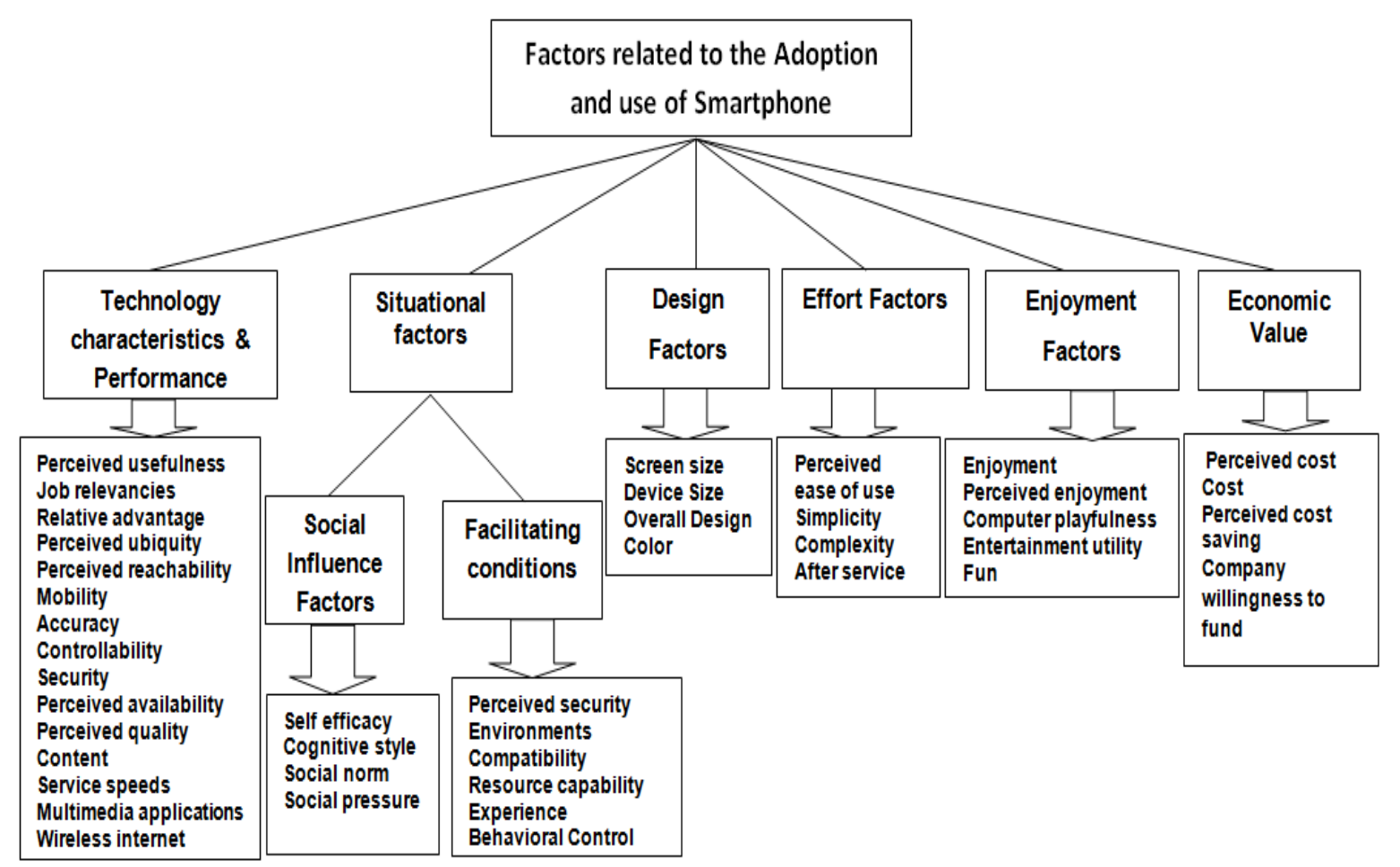

Figure 1: taxonomy of factors related to the adoption and use of the Smartphone

\section{DEVELOPING RESEARCH THEORETICAL MODEL}

Sekaran [79] defined a theoretical framework or model as " a conceptual model for how one theorizes or makes logical sense of the relationships among the several factors that have been identified as important to the research problem". Also, he mentioned that identifying the factors that have been determined as important factors by previous research accompanied with rational relationships and connections that can be logically conceptualized to form the basis of a research theoretical framework or model [79]. A literature review of related IT adoption theoretical models has been conducted as mentioned earlier in this research review related theoretical models including TRA, TAM, TPB, IDT, TTF and UTAUT. UTAUT is an established theoretical model with four main constructs that determine users' intention and use of a new technology [45]. Venkatesh et al. [45] empirically tested the UTAUT model and confirmed that UTAUT outperforms each of the prominent eight models initially used in forming UTAUT. In order to make the UTAUT more comprehensive model, the developer of the UTAUT model integrated a number of important factors under each main construct of the UTAUT model. For example integrating the perceived usefulness factor under the performance expectancy construct which indicates that any factor that contributes to the perceived usefulness factor can perhaps contribute into performance expectancy construct. UTAUT propose a better unified view of the users' acceptance of a technology and it is expected to explain about $70 \%$ of variances [45]. The UTAUT model has been modified, extended and integrated with other IT theoretical models to study and explain adoption and use of technology related to the Smartphone technology. Choudrie et al. [60] combined UTAUT with TAM and DOI to study the adoption and use of the Smartphone by older adults in the United Kingdom. Shin et al. [65] extended the UTAUT model study key factors the influence users' intentions to continue using the Smartphone as a ubiquitous learning (u-learning) tool. Boontarig et al. [77] extended UTAUT to examine the factors that Influence the Thai elderly Intention to use Smartphone for e-Health services. Tao and Zhou [70] modified UTAUT model to study the key factors that influence users' acceptance and use of mobile commerce. Yun et al. [82] extended UTAUT to explain and predict users intention to use location-based services (LBS) ,application used on the Smartphone technology. Therefore, UTAUT model is a suitable model and it has been selected to be the base for this research model and it has been modified and developed based on the literature review, the results of the brainstorming session, group focus and the individual interviews. Factors that are selected by at least two-thirds of the participants in the brainstorming, focus group and the interview will be considered and utilized in developing and modifying the research model.

A. Qualitative methods utilized to review, evaluate, select and validate factors identified through literature review

Theoretical model can be developed through literature review of the previous research related to the subject under 
consideration and through conducting interviews with the people who are knowledgeable of the specific subject under consideration [79]. Literature review has been conducted to explore research related to the adoption of the Smartphone technology as shown earlier in this research. A number of factors related to the adoption and use of the Smartphone have been identified. In addition to literature review, the researcher conducted a number of qualitative methods namely; brainstorming sessions, focus group session and individuals interviews. The aim of using the mentioned methods is to explore and introduce new factors that were not covered in the literature review and to review, evaluate, validate and select the important factors that are more associated with users' adoption and use of the Smartphone. The qualitative methods mentioned above have been used in many research in different disciplines including research related to IT adoption [84], in research related to healthcare sector [85], in research related to education sector [86] and many more. Experienced users of the Smartphone with different work background can be a valuable source that can provide more insight into the factors that may have relationship with users' adoption and use of the Smartphone. Also, individuals who work in Smartphone industry and its related sectors can be a valuable source that can provide valuable information about factors associated with users' adoption and use of the Smartphone. Therefore, the researcher targeted experienced users of the Smartphone from different background and individuals who work in Smartphone industry and its related sectors to be participants in the qualitative methods for this research.

\section{B. Brainstorming session}

Brainstorming is defined as "a term that is now commonly used for group sessions in which people share ideas on some issue or problem" [87]. Brainstorming can be thought of as a mean to increase creativity to generate a wide range of ideas regarding solving or discussing a particular issue [88, 89]. Brainstorming approach have been used by number of scholars to introduce and evaluate factors related to mobile technologies [84]. The brainstorming session aims to gather as many ideas and thought related to the issue under consideration as possible [90]. The aim of the brainstorming session in this research is to obtain experienced users' creative ideas and thought in introducing new factors that may have relationship with users' adoption and use of the Smartphone and evaluating the factors identified in the literature review. Participants have introduced a number of new factors and discussed them during this session. Also, the participants reviewed and evaluated the list of factors provided to them then they selected number of factors that they believe is more important and can be included in the research model. Brainstorming session has been conducted with 6 participants and it took around an hour and 10 minutes.

\section{Focus Group}

Scholars indicated that there is a value of using number of qualitative approaches also they mentioned the usefulness of combining in depth interviews and focus group approaches [91]. Focus groups method can be utilize as an initial level to raise and explore relevant key issues related to the subject under consideration and then these key issues can be discussed in more depth using in depth individuals' interviews $[92,91]$. Therefore, in this research focus group session was conducted to obtain participants' opinions and perspective about factors that are more associated with users' adoption and use the Smartphone and give the participants the chance to introduce new related factors. Group technique is a group interview that has been used extensively in many fields to obtain the perceptions and feelings of participants around a specific issue [92]. The focus group session is topically conducted to obtain participants' impressions, point views and opinions as the participants are invited to discuss and talk about a specific issue [79]. Participants have reviewed, evaluated and discussed the list of factors provided to them then they selected a number of factors that they believe is more important and can be included in the research model. Focus group session has been conducted with 7 participants and it took around an hour.

\section{Individuals Interviews}

Interview is a qualitative research method used to collect data and it is defined as a type of conversation with propose [91]. Individual interviews are one of the most widely used methods in qualitative research [91]. In-depth interviews mostly provide an opportunity for researcher to obtain more detailed investigation of each individual's personal perspective about the issue under consideration [91]. Experienced users of the Smartphone and individuals who work in sectors related to the Smartphone industry were invited to participate in these individual interviews. The main aim of the individual interviews in this research is to obtain the participants' deep perspectives and thought about the key factors that they believe are associated with users' adoption and use of the Smartphone. Each interviewee had reviewed, evaluated and discuss each factor in the list and provide feedback on what are the factors that they believe is more important and can be included in the research model. Individual interview gave the research a better chance to have in depth discussion with each participant. A total of twenty individual face to face interviews have been conducted and it differs in time duration which range from about 20 minutes to about an hour.

\section{E. Results and discussion}

More than forty factors related to the users' adoption and use of smartphones have been identified through a literature review conducted for this research as shown table 3 .

Table 4 summarize methods used, its objectives, the number of factors introduced in each method. 
TABLE 3: FACTORS IDENTIFIED THROUGH LITERATURE REVIEW

\begin{tabular}{|l|}
\hline Factors derived from literature \\
\hline$>$ Performance expectancy \\
\hline$>$ Task Technology Fit \\
\hline$>$ Perceived ubiquity \\
\hline$>$ Perceived reachability \\
\hline$>$ Mobility \\
\hline$>$ Accuracy \\
\hline$>$ Controllability \\
\hline$>$ Security \\
\hline$>$ Perceived availability \\
\hline$>$ Perceived quality \\
\hline$>$ Content \\
\hline$>$ Screen size \\
\hline$>$ Service speeds \\
\hline$>$ Design \\
\hline$>$ Multimedia \\
\hline$>$ Applications \\
\hline$>$ Wireless Internet \\
\hline
\end{tabular}

\begin{tabular}{|l|l|}
\hline$>$ Effort expectancy & $>$ Perceivedenjoyment \\
\hline$>$ Simplicity & $>$ Computer playfulness \\
\hline$>$ Complexity & $>$ Fun \\
\hline$>$ Self-efficacy & $>$ Entertainment utility \\
\hline$>$ Social norm & $>$ After service \\
\hline$>$ Social pressure & $>$ Resource capability \\
\hline$>$ Facilitating conditions & \\
\hline$>$ Environments & \\
\hline$>$ Organizational & \\
\hline$>$ Compatibility & \\
\hline$>$ Behavior control & \\
\hline$>$ Price value & \\
\hline$>$ Perceived cost & \\
\hline$>$ Cost \\
\hline$>$ Perceived cost saving \\
\hline$>$ Company willingness to fund \\
\hline$>$ Enjoyment \\
\hline
\end{tabular}

TABLE 4: NUMBER OF FACTORS INTRODUCED IN EACH METHOD

\begin{tabular}{|c|c|c|c|}
\hline Method & Objectives & $\begin{array}{c}\text { Number of } \\
\text { factors }\end{array}$ & Total \\
\hline Literature review & Identify factors that have been identified in previous related research & 42 & 42 \\
\hline Brainstorming session & $\begin{array}{l}\text { To gather as many ideas and thought that can introduce new factors. Also, participants were asked to } \\
\text { evaluate, select and validate factors identified through literature review. }\end{array}$ & 6 & 48 \\
\hline Focus group session & $\begin{array}{l}\text { The main objective of conducting focus group is to obtain participants' impressions, feeling, point } \\
\text { views and opinions to evaluate, select and validate the factors identified through literature review and } \\
\text { brainstorming session. Discussion among participants will encourage participants to refine their } \\
\text { perception Also, participants were asked to introduce new factors if they have any. }\end{array}$ & 1 & 49 \\
\hline Individual interviews & $\begin{array}{l}\text { To obtain individuals' perspective, point views, and opinions to evaluate, select and validate the factors } \\
\text { identified through literature review, brainstorming and focus group. Also, participants were asked to } \\
\text { introduce new factor that are not identified }\end{array}$ & 3 & 52 \\
\hline
\end{tabular}

A total of thirty three participants have participated in the qualitative methods conducted for this research; six participants in the brainstorming session, seven participants in the focus group session and twenty participants in the individual face to face interviews. Factors that have been selected by at least two-third of the participants will be included in the research model. the results showed that, a total of eight factors have been selected by at least tow-third (22) of the participants namely: performance expectancy factor has been selected by 31 participants, social influence factor has been selected by 26 participants, brand influence factor has been selected by 25 participants, effort expectancy factor has been selected by 24 participants, economic factors factor has been selected by 24 participants, facilitating conditions factor has been selected by 23 participants, received enjoyment factor has been selected by 23 participants and design factor has been selected by 22 participants. The research model, shown in figure 2 below, is based on UTAUT model and it has been modified based on the literature review and the qualitative methods that have been conducted for this research.

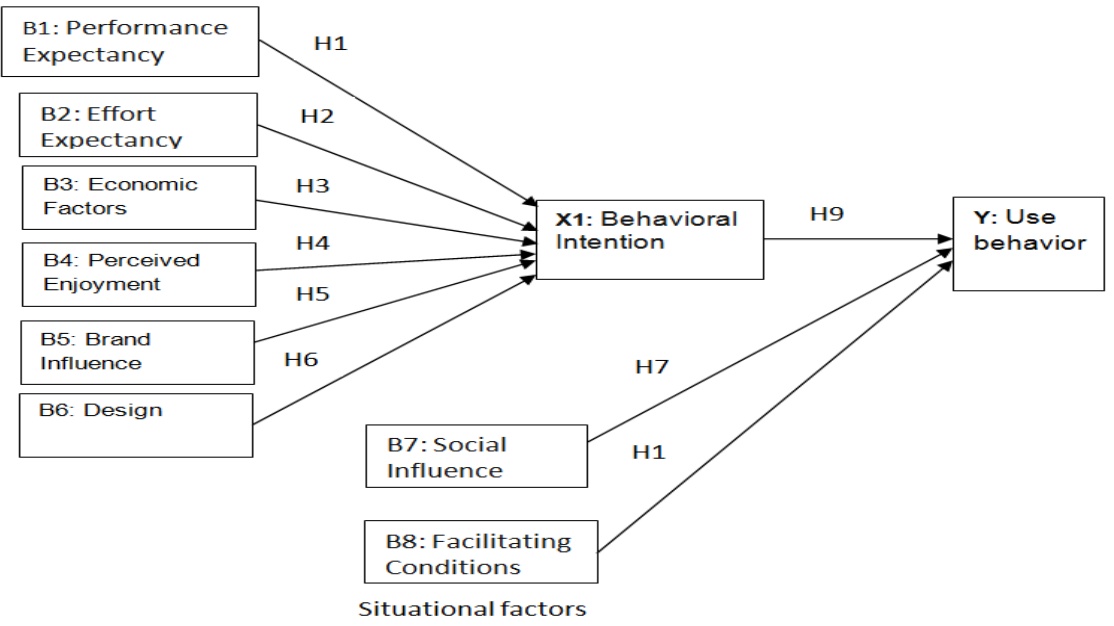

Figure 2: modified research model 


\section{DEVELOPING THE RESEARCH HYPOTHESES}

B1: Performance expectancy construct: defined as "the degree to which an individual believes that using an information system will help him or her to attain benefits in job performance" [45]. Smartphone technology can benefits the users in their job environment and other environments. Therefore, for the purposes of this research, the original definition of performance expectancy will be modified to be "the degree to which an individual believes that using the Smartphone technology will help him or her to attain benefits in their overall performance." The performance expectancy construct has a strong relationship with intention and it is a key predictor of the users' intention to adopt and use a technology [45]. The Smartphone provides users with many features and benefits that can help to improve their overall performance. Choudrie et al. [60] studied the adoption and use of the Smartphone by older adults in the United Kingdom. Their finding showed that, performance expectancy construct has the strongest influence on intention to adopt and use of Smartphone [60]. Performance expectancy construct has been selected by at least two-thirds of the participants in the brainstorming, focus group and the interviews as an important factor that may have relationship with users' adoption and use of the smartphone. Therefore, the following hypothesis is created to test the relationship between the performance expectation construct and users' intention to adopt and use the Smartphone technology.

H1: Performance expectancy construct will have a positive relationship with the users' behavioral intention to use the Smartphone technology.

B2: Effort expectancy construct: defined as "the degree of ease associated with the use of systems" [45]. The effort expectancy construct reflects users' views or perceptions of the level or degree of ease of use or simplicity associated with the use of the Smartphone technology. There are a number of factors that were identified in previous research that are associated with level of effort expectancy when using the Smartphone and its related technologies namely simplicity [75], design [36], and complexity [68]. These factors were either directly associated with the effort expectancy construct or through other factors such as the ease of use factor [81, 36, 67, 20, 78]. Boontarig et al. [77] studied the key factors that influence the elderly's intention to use the Smartphone for e-Health services in Thailand. They finding includes that effort expectancy factor has a significant influence on the Thai elderly's intention to use the Smartphone for e-health services [77]. Choudrie et al. [60], in their investigation of factors that influence adoption and use of Smartphone among older adults, found that effort expectancy construct has a significant influence on users' intention to adopt and use of Smartphone. Effort expectancy construct has been selected by at least two-thirds of the participants in the brainstorming, focus group and the interviews as an important factor that may have relationship with users' adoption and use of the smartphone. Therefore, the following hypothesis is created to test the relationship between the effort expectancy construct and users' intention to adopt and use the Smartphone technology.

H2: Effort expectancy construct will have a positive relationship with the users' behavioral intention to adopt and use the Smartphone technology.

B3: Economic factors Construct: Individuals users usually pay close attention to the price and cost of a technology before considering adopting and using that technology. Economic factors can be defined as the perceived value of the tradeoff between the perceived benefits of the technologies and the cost for acquiring and using it [93, 94]. Economic factors were identified as a construct that can predict users' behavioral intention to adopt and use new IT [94]. When the perceived benefits of acquiring and using a technology is perceived to be greater than the cost, the economic factors are expected to have a positive relationship with users' intention to adopt and use a technology [94]. The price of the Smartphone' devices and its services can be costly for some users which can negatively influence their intention to adoption and use the Smartphone. If users perceived Smartphone technology as cost effective technology, they may be more willing to adopt and use it. In a number of empirical research related the adoption and use of Smartphone technology, price or cost of the technology showed significant relationship with users' intention to adopt and sue it. Kim [54] studied the factors that influence users to adopt and use of mobile wireless technology (MWT) via the Smartphone technology. In his results, perceived cost saving showed a positive relationship with users behavioral intention to use the MWT via Smartphone. Kim et al. [95] investigated factors that influence the adoption and use mobile internet. They found that, cost or the price of mobile internet has a significant relationship with users' intention to adopt mobile technology [95]. A number of factors related to economic factors namely perceived cost [67], perceived cost saving [54], company willingness to found [54] were determined in previous research as important factors that are associated with users' adoption and use of the Smartphone. Economic factors construct has been selected by at least two-thirds of the participants in the brainstorming, focus group and the interviews as an important factor that may have relationship with users' adoption and use of the smartphone. Thus, the following hypothesis is created to test the relationship between the value price construct and users' intention to adopt and use the Smartphone technology.

H3: Economic factors construct will have a positive relationship with the users' behavioral intention to adopt and use the Smartphone technology.

B4: Perceived enjoyment: considered to be a significant predictor of users' intention to adopt and use information technology [96, 97]. Moreover, perceived enjoyment construct has been selected by at least two-thirds of the 


\section{Proceedings of PICMET '15: Management of the Technology Age}

participants in the brainstorming, focus group and the interviews as an important factor that may have relationship with users' adoption and use of the Smartphone. Therefore, the following hypothesis is created to test the relationship between the perceived enjoyment construct and users' intention to adopt and use the Smartphone technology.

H4: Perceived enjoyment construct will have a positive relationship with users' behavioral intention to adopt and use the Smartphone technology.

B5: Brand Influence: Studying the brand influence on the adoption and use of Smartphone technology was an approach that a number of scholars used in their research [62, 63]. Based on Ganesh and Kumar's work, Chris Maloney [63] developed a framework to explore the learning effects' influence on the rate of adoption in the market to better explain the impact of the learning effect on adoption rate of the iPhone [63]. Also, Kim and Song [62] investigated the adoption and use of Blueberry Smartphone. They developed their own research model that investigated the social, economic, and technological characteristics that influence individuals' attitude toward adoption of a specific Smartphone device, namely Blueberry. Even though Smartphone device brands such as Nokia, HTC, and Samsung have their own unique differences in their combination of hardware/software, and they may influence user's acceptance and attitude toward adoption of Smartphone differently, the iphone was the most studied Smartphone device by scholars in articles reviewed [98-102]. Brand influence construct has been selected by at least two-thirds of the participants in the brainstorming, focus group and the interviews as an important factor that may have relationship with users' adoption and use of the smartphone. Therefore, the following hypothesis is created to test the relationship between the brand influence construct and users' intention to adopt and use the Smartphone technology

H5: Brand influence construct will have a positive relationship with the users' behavioral intention to adopt and use the Smartphone technology.

B6: Design: Aesthetic design of smartphones have been studied to observe how it affects users' emotional reaction towards adoption of the Smartphone device [103]. In a research focused on undergraduate and graduate students in Korea, Kang et al. [36] analyzed the factors that may affect the adoption of Smartphone. Their finding indicated that, design factor an important factor that have positive relationship with perceived usefulness which in return have an effect on behavioral intention. Design factor has been selected by at least two-thirds of the participants in the brainstorming, focus group and the interviews as an important factor that may have relationship with users' adoption and use of the smartphone. Therefore, the following hypothesis is created to test the relationship between the design construct and users' intention to adopt and use the Smartphone technology.
H6: Design construct will have a positive relationship with the users' behavioral intention to adopt and use the Smartphone technology.

\section{Situational factors}

Consumer or users situation can be viewed as comprising "of all those factors particular to a time and place of observation which do not follow from knowledge of personal (infra-individual) and stimulus (choice alternative) attributes and which have a demonstrable and systematic effect on current behavior" [104]. Clearer accounting for situational variables can greatly improve the researcher's ability to predict and understand consumers' actual behavioral [105]. Ward and Robertson stated that "situational variables may account for considerably more variance than actor related variables" [106]. it was indicated that key situational variables have shown significant effects on behavior and it is important to consider it with other related factors to obtain better explanation of consumers' behavior [105]. both individual and situational factors must be considered in order to explain consumer choices[105]. It was mentioned that both individual and situational factors must be accounted for to better explain users' actual use[105]. Actual behavior of using or buy a technology usually happens within a situational context and that situation may act as a means to facilitate or to inhibit the happening of that actual behavior or it may not affect it at all[107]. Number of scholars identified a number of general variables that can be characterize as situational factors including [105, 107]:

- Physical surroundings

- Social influence or social surroundings such as other persons present, their characteristics, their apparent roles, and interpersonal Interactions,

- Time horizon

- Past experience.

Alavi and Joachimsthaler mentioned that user situational variables as one of the most relevant user factors that can help to determine the acceptance of technology [108]. A number of situational factors are presented in the primarily research model namely facilitating condition and social influence and two hypotheses are developed.

B7: Social influence: social influence is defined as "the extent to which a person perceives that important others believe he or she should use a new information system" [45]. Subjective norms and social influence have been recognized as important aspects that influence users' adoption of a new technology [109]. A number of factors, namely self-efficacy [20], social norms [53], and social pressure [78] were determined in previous research as important factors that are related to social influence on users' adoption of and use of the Smartphone. Pan et al. [33] studied the key factors that influence the adoption of the Smartphone among college students in China and they indicated that, social influence has 
a significant and positive influence on users' adoption of the Smartphone [33]. Ling and Yuan [34] empirically study the factors that influence users' adoption and use the Smartphone in China and they found that, subjective norms were among the significant factors that have positive effects on users' adoption and use the Smartphone [34]. Scholars pointed out the important role of cultural factors and its influence on the adoption use of new information technologies [25-29]. Saudi society has different cultural contexts in that it is characterized as a society that is more collectivist in nature in which individuals have closer ties and influential effects among them [25]. Social Influence construct has been selected by at least two-thirds of the participants in the brainstorming, focus group and the interviews as an important factor that may have relationship with use behavior construct. Therefore, the following hypothesis is created to test the relationship between the social influence construct and users' use behavior of Smartphone technology.

H7: Social Influence construct will have a positive relationship with the use behavior construct.

B8: Facilitating conditions: defined as "the degree to which an individual believes that an organizational and technical infrastructure exists to support use of the system" [45]. In the Smartphone technology facilitating conditions can include connectivity and internet service availability, services support, usage information, system compatibility, individual financial resource, and more factors that facilitate better use of this technology. A number of factors that are related to facilitating conditions including perceived security [68], environments [22, 20], organizational [22, 20], compatibility $[22,67,20]$, internal environment [78] and external environment [78], were determined in previous research as important factors that are associated with users' adoption and use of the Smartphone. Boontarig et al. [77] invstagated the key factors that influence the Thai elderly's intention to use the Smartphone for e-Health services. They found that facilitating conditions construct has a significant influence on the Thai elderly intention to use the Smartphone for e-health services [77]. Choudrie et al. [60], in their study of factors that influence adoption and use of Smartphone among older adults, found that facilitating conditions construct is important factors that has a significant influence on users' intention to adopt and use of Smartphone. Facilitating conditions construct has been selected by at least two-thirds of the participants in the brainstorming, focus group and the interviews as an important factor that may have relationship with use behavior construct. Therefore, the following hypothesis is created to test the relationship between the facilitating conditions construct and the use behavior.

H8: Facilitating conditions construct will have a positive relationship with the use behavior regarding the Smartphone technology.
X1: Behavioral Intention is expected to have a positive relationship with the facilitating conditions construct and with social factors constructs. Therefore, in this proposed research, behavioral intention is expected to have a positive relationship the facilitating conditions construct and with social factors constructs which in turn will have a positive relationship with use behavior construct. Thus, the following hypothesis is created.

H9: Behavioral intentions construct will have a positive relationship with the Use behavior construct.

\section{CONCLUSION}

An extensive literature review has been conducted to obtain more insight into the existing research related to the adoption and use of smartphones and the theoretical models that have been utilized in previous related research. Taxonomy of factors related to the adoption and use of smartphones has been developed based on literature review. More than forty factors related to the adoption and use of smartphones has been identified in previous research. A theoretical research model has been developed for this research based on UTAUT model. A number of qualitative methods have been conducted to review, elevate, validate, and select the more related factors that can be added and used in the research model. Based on the literature review and the results of the qualitative methods conducted, the research model have been modified and finalized. Moreover, hypotheses have been developed to explain and test the relationships among factors in the research model. The next future step in this research is to design a web survey instrument and that will be administered to users of smartphones in Saudi Arabia to test the developed hypotheses that have been created and explore the key factors that have relationships with users' adoption and use of smartphones.

\section{REFERENCES}

[1] V. Venkatesh, "Determinants of perceived ease of use: Integrating control, intrinsic motivation, and emotion into the technology acceptance model," Information systems research, vol. 11, pp. 342365,2000

[2] A. Dillon and M. G. Morris, "User acceptance of information technology: theories and models," in Annual review of information science and technology. Vol.31, ed Medford, NJ, USA: Information Today, 1996, pp. 3-32.

[3] A. L. Gilbert and H. Han, "Understanding mobile data services adoption: demography, attitudes or needs?," Technological Forecasting and Social Change, vol. 72, pp. 327-337, 2005.

[4] A. M. Kaplan, "If you love something, let it go mobile: Mobile marketing and mobile social media 4x4," Business Horizons, vol. 55, pp. 129-139, 2012.

[5] S. Santhipriya, B. Sastry, and K. Akshitha, "Securing Smartphone Apps In Online Environment," International Journal of Mathematical Archive (IJMA) ISSN 2229-5046, vol. 2, 2011.

[6] S. Alwahaishi and V. Snášel, "Factors Influencing The Consumer' Adoption Of Mobile Internet," in The Third International Conference on Digital Information and Communication Technology and its Applications (DICTAP2013), 2013, pp. 31-39. 
[7] E. G. Carayannis and S. C. Clark, "Do smartphones make for smarter business? The smartphone CEO study," Journal of the Knowledge Economy, vol. 2, pp. 201-233, 2011.

[8] A. J. Rohm, T. T. Gao, F. Sultan, and M. Pagani, "Brand in the hand: A cross-market investigation of consumer acceptance of mobile marketing," Business Horizons, vol. 55, pp. 485-493, 2012.

[9] H. Chun, H. Lee, and D. Kim, "The integrated model of smartphone adoption: Hedonic and utilitarian value perceptions of smartphones among Korean college students," Cyberpsychology, Behavior, and Social Networking, vol. 15, pp. 473-479, 2012.

[10] S. M. Goldman, "Transformers," Journal of Consumer Marketing, vol. 27, pp. 469-473, 2010.

[11] B. Saddik, D. Barakah, and B. Aldosari, "A study of PDA and Smartphone adoption rates at King Saud Medical City Hospitals," in Medical Information and Communication Technology (ISMICT), 2012 6th International Symposium on, 2012, pp. 1-3.

[12] (3/30/2014). Global market share held by the leading smartphone operating systems in sales to end users from 1st quarter 2009 to 4th quarter $2013 . \quad$ Available: http://www.statista.com/statistics/266136/global-market-share-heldby-smartphone-operating-systems/

[13] M. Kenney and B. Pon, "Structuring the smartphone industry: is the mobile internet OS platform the key?," Journal of Industry, Competition and Trade, vol. 11, pp. 239-261, 2011.

[14] H. Dai and P. C. Palvi, "Mobile commerce adoption in China and the United States: a cross-cultural study," ACM SIGMIS Database, vol. 40, pp. 43-61, 2009.

[15] F.-M. Tseng, Y.-L. Liu, and H.-H. Wu, "Market penetration among competitive innovation products: The case of the Smartphone Operating System," Journal of Engineering and Technology Management.

[16] S. A. Vannoy and P. Palvia, "The social influence model of technology adoption," Communications of the ACM, vol. 53, pp. 149$153,2010$.

[17] M. S. Chtourou and N. Souiden, "Rethinking the TAM model: time to consider fun," Journal of Consumer Marketing, vol. 27, pp. 336-344, 2010.

[18] Y. Song and J. Han, "Is Enjoyment Important? An Empirical Research on the Impact of Perceive Enjoyment on Adoption of New Technology," in International Conference on Information Management, Innovation Management and Industrial Engineering, 2009, pp. 511-514.

[19] B. Kijsanayotin, S. Pannarunothai, and S. M. Speedie, "Factors influencing health information technology adoption in Thailand's community health centers: Applying the UTAUT model," International Journal of Medical Informatics, vol. 78, pp. 404-416, 2009.

[20] Y. Park and J. V. Chen, "Acceptance and adoption of the innovative use of smartphone," Industrial Management \& Data Systems, vol. 107, pp. 1349-1365, 2007.

[21] G. J. Putzer and Y. Park, "The effects of innovation factors on smartphone adoption among nurses in community hospitals," Perspectives in health information management/AHIMA, American Health Information Management Association, vol. 7, 2010.

[22] J. V. Chen, D. C. Yen, and K. Chen, "The acceptance and diffusion of the innovative smart phone use: A case study of a delivery service company in logistics," Information \& Management, vol. 46, pp. 241$248,2009$.

[23] S. Y. Lee, "Examining the factors that influence early adopters' smartphone adoption: The case of college students," Telematics and Informatics, vol. 31, pp. 308-318, 2014.

[24] L. G. Tornatzky and K. J. Klein, "Innovation characteristics and innovation adoption-implementation: A meta-analysis of findings," IEEE Transactions on Engineering Management, vol. EM-29, pp. 2845, 1982.

[25] S. S. Al-Gahtani, G. S. Hubona, and J. Wang, "Information technology (IT) in Saudi Arabia: Culture and the acceptance and use of IT," Information \& Management, vol. 44, pp. 681-691, 2007.

[26] P. A. Herbig and F. Palumbo, "The effect of culture on the adoption process: A comparison of Japanese and American behavior,"
Technological Forecasting and Social Change, vol. 46, pp. 71-101, 1994.

[27] D. Straub, M. Keil, and W. Brenner, "Testing the technology acceptance model across cultures: A three country study," Information \& Management, vol. 33, pp. 1-11, 1997.

[28] D. W. Straub, "The Effect of Culture on IT Diffusion: E-Mail and FAX in Japan and the US," Information Systems Research, vol. 5, pp. 23-47, 1994

[29] Y. M. Van Everdingen and E. Waarts, "The effect of national culture on the adoption of innovations," Marketing Letters, vol. 14, pp. 217232, 2003.

[30] W. A. Al-Ghaith, L. Sanzogni, and K. Sandhu, "Factors influencing the adoption and usage of online services in Saudi Arabia," The Electronic Journal of Information Systems in Developing Countries, vol. 40, 2010.

[31] J. Que and V. Hurtado. 10/30/2013). The rise of Saudi Arabian telecoms: Unrivalled promise and opportunity in a vibrant market. Available:

http://www.deltapartnersgroup.com/our_insights/whitepapers/the-riseof-saudi-telecoms-unrivalled-promise-and-opportunity-in-a-vibrantmarket

[32] I. Arpaci, Y. C. Yardimci, and O. Turetken, "The impact of cultural differences on smartphone adoption by organizations," in Innovative Computing Technology (INTECH), 2013 Third International Conference on, 2013, pp. 421-423.

[33] D. Pan, N. Chen, and P.-L. P. Rau, "The Acceptance and Adoption of Smartphone Use among Chinese College Students," in Cross-Cultural Design. Methods, Practice, and Case Studies, ed: Springer, 2013, pp. 450-458.

[34] M. Ling and P. Yuan, "An empirical research: Consumer intention to use smartphone based on consumer innovativeness," in Consumer Electronics, Communications and Networks (CECNet), 2012 2nd International Conference on, 2012, pp. 2368-2371.

[35] C. E. Hill, K. D. Loch, D. Straub, and K. El-Sheshai, "A qualitative assessment of Arab culture and information technology transfer," Journal of Global Information Management (JGIM), vol. 6, pp. 2938, 1998.

[36] Y. M. Kang, C. Cho, and S. Lee, "Analysis of factors affecting the adoption of smartphones," in 1st International Technology Management Conference (ITMC), San Jose, CA, United states, 2011, pp. 919-925.

[37] R. F. Perozzo and C. E. Pereira, "Management of services in intelligent environments for mobile devices," in 4th International Conference on Intelligent Environments, Seattle, WA, United states, 2008.

[38] H. Verkasalo, "Analysis of smartphone user behavior," in Ninth International Conference on Mobile Business and Global Mobility Roundtable (ICMB-GMR), 2010, pp. 258-263.

[39] S. A. Al-Meshal and M. A. Almotairi, "Consumer Acceptance of Mobile Marketing: An Empirical Study on the Saudi Female," International Journal of Marketing Studies, vol. 5, 2013.

[40] A. Alsenaidy and A. Tauseef, "A Review of Current State M Government in Saudi Arabia," Global Engineers \& Technologists Review, vol. 2, pp. 5-8, 2012.

[41] M. E. Seliaman and M. Al-Turki, "Mobile Learning Adoption in Saudi Arabia," in Proceedings of World Academy of Science, Engineering and Technology, 2012.

[42] G. C. Moore and I. Benbasat, "Development of an instrument to measure the perceptions of adopting an information technology innovation," Information systems research, vol. 2, pp. 192-222, 1991.

[43] A. Dillon and M. G. Morris, "User acceptance of new information technology: theories and models," Annual Review of Information Science and Technology, vol. 14, pp. 3-32, 1996.

[44] S. Taylor and P. A. Todd, "Understanding information technology usage: A test of competing models," Information systems research, vol. 6, pp. 144-176, 1995.

[45] V. Venkatesh, M. G. Morris, G. B. Davis, and F. D. Davis, "User acceptance of information technology: Toward a unified view," Management Information Systems (MIS), vol. 27, pp. 425-478, 2003. 
[46] I. Ajzen, "The theory of planned behavior.," Organizational Behavior and Human Decision Processes, vol. 50, pp. 179-211, 1991.

[47] F. D. Davis, "Perceived usefulness, perceived ease of use, and user acceptance of information technology," MIS Q., vol. 13, pp. 319-340, 1989.

[48] S. Heshan and Z. Ping, "A methodological analysis of user technology acceptance," in Proceedings of the 37th Annual Hawaii International Conference on System Sciences, 5-8 Jan. 2004, Los Alamitos, CA, USA, 2004, p. 10 pp.

[49] Y. Lee, K. A. Kozar, and K. R. Larsen, "The technology acceptance model: past, present, and future," The Communications of the Association for Information Systems, vol. 12, pp. 752-780., 2003.

[50] F. D. Davis, R. P. Bagozzi, and P. R. Warshaw, "User acceptance of computer technology: a comparison of two theoretical models," Management Science, vol. 35, pp. 982-1003, 1989.

[51] H. Rui and L. Lu, "The diffusion and adoption research of mobile commerce-A Review," in Management and Service Science, 2009. MASS'09. International Conference on, 2009, pp. 1-5.

[52] Y. W. Sawng and H. S. Han, "Market analysis for the next-generation mobile communications (DMB) service from the perspective of innovation adoption and diffusion," International Journal of Satellite Communications and Networking, vol. 25, pp. 323-348, 2007.

[53] H. Verkasalo, C. López-Nicolás, F. J. Molina-Castillo, and H. Bouwman, "Analysis of users and non-users of smartphone applications," Telematics and Informatics, vol. 27, pp. 242-255, 2010.

[54] K. Sang Hyun, "Moderating effects of job relevance and experience on mobile wireless technology acceptance: adoption of a smart phone by individuals," Information and Management, vol. 45, pp. 387-93, 2008.

[55] P. Legris, J. Ingham, and P. Collerette, "Why do people use information technology? A critical review of the technology acceptance model," Information and Management, vol. 40, pp. 191204, 2003.

[56] Z. Liu, Q. Min, and S. Ji, "A comprehensive review of research in IT adoption," in Wireless Communications, Networking and Mobile Computing, 2008. WiCOM'08. 4th International Conference on, 2008, pp. 1-5.

[57] M. Conner and C. J. Armitage, "Extending the theory of planned behavior: A review and avenues for further research," Journal of applied social psychology, vol. 28, pp. 1429-1464, 1998.

[58] D. L. Goodhue and R. L. Thompson, "Task-technology fit and individual performance," MIS Q., vol. 19, pp. 213-236, 1995.

[59] F. Aldhaban, "Exploring the adoption of Smartphone technology: Literature review," in Technology Management for Emerging Technologies (PICMET), 2012 Proceedings of PICMET'12:, 2012, pp. 2758-2770.

[60] J. Choudrie, S. Pheeraphuttharangkoon, E. Zamani, and G. Giaglis, "Investigating the adoption and use of smartphones in the UK: a silver-surfers perspective," 2014.

[61] J. Huang, Q. Xu, B. Tiwana, Z. M. Mao, M. Zhang, and P. Bahl, "Anatomizing application performance differences on smartphones," in Proceedings of the 8th international conference on Mobile systems, applications, and services, 2010, pp. 165-178.

[62] S. Kim and Y. Song, "Determinants Influencing Individuals' Likelihood of Adopting and Actual use of Blueberry," Journal of Applied Sciences, vol. 9, pp. 3662-3671, 2009.

[63] C. Maloney. (2009). the Newton ball multi-National diffusion acceleration effect: an apple iPhone case study. . Available: http://chrismaloney.files.wordpress.com/2009/06/newton-ball-multinational-diffusion-acceleration-effect-an-apple-iphone-casestudy1.pdf

[64] D. Schuurman, C. Courtois, and L. De Marez, "New media adoption and usage among Flemish youngsters," Telematics and Informatics, vol. 28, pp. 77-85, 2011.

[65] D.-H. Shin, Y.-J. Shin, H. Choo, and K. Beom, "Smartphones as smart pedagogical tools: Implications for smartphones as u-learning devices," Computers in Human Behavior, vol. 27, pp. 2207-2214, 2011.
[66] T. Zhou, Y. Lu, and B. Wang, "Integrating TTF and UTAUT to explain mobile banking user adoption," Computers in Human Behavior, vol. 26, pp. 760-767, 2010.

[67] N. Koenig-Lewis, A. Palmer, and A. Moll, "Predicting young consumers' take up of mobile banking services," International Journal of Bank Marketing, vol. 28, pp. 410-432, 2010.

[68] N. Mallat, "Exploring consumer adoption of mobile payments - A qualitative study," Journal of Strategic Information Systems, vol. 16, pp. 413-432, 2007.

[69] H. H. Bauer, S. J. Barnes, T. Reichardt, and M. M. Neumann, "Driving consumer acceptance of mobile marketing: A theoretical framework and empirical study," Journal of electronic commerce research, vol. 6, pp. 181-192, 2005.

[70] T. Zhou, "Exploring mobile user acceptance based on UTAUT and contextual offering," in Electronic Commerce and Security, 2008 International Symposium on, 2008, pp. 241-245.

[71] J.-H. Wu and S.-C. Wang, "What drives mobile commerce?: An empirical evaluation of the revised technology acceptance model," Information \& management, vol. 42, pp. 719-729, 2005.

[72] R. Xia, M. Rost, and L. E. Holmquist, "Business models in the mobile ecosystem," in Mobile Business and 2010 Ninth Global Mobility Roundtable (ICMB-GMR), 2010 Ninth International Conference on, 2010, pp. 1-8.

[73] F. Lin and W. Ye, "Operating system battle in the ecosystem of smartphone industry," in Information Engineering and Electronic Commerce, 2009. IEEC'09. International Symposium on, 2009, pp. 617-621.

[74] B. Beurer-Zuellig and M. Meckel, "Smartphones enabling mobile collaboration," in Hawaii International Conference on System Sciences, Proceedings of the 41st Annual, 2008, pp. 49-49.

[75] B. Kargin, N. Basoglu, and T. Daim, "Exploring mobile service adoption: A conjoint model," in Portland International Conference on Management of Engineering and Technology (PICMET), 2008, pp. 2623-2633.

[76] S. Kim and G. Garrison, "Investigating mobile wireless technology adoption: An extension of the technology acceptance model," Information Systems Frontiers, vol. 11, pp. 323-333, 2009.

[77] W. Boontarig, W. Chutimaskul, V. Chongsuphajaisiddhi, and B. Papasratorn, "Factors influencing the Thai elderly intention to use smartphone for e-Health services," in Humanities, Science and Engineering Research (SHUSER), 2012 IEEE Symposium on, 2012, pp. 479-483.

[78] D.-H. Shin, "User acceptance of mobile Internet: Implication for convergence technologies," Interacting with Computers, vol. 19, pp. 472-483, 2007.

[79] U. Sekaran, Research methods for business: A skill building approach, 4th ed.: John Wiley \& Sons, 2003.

[80] F. D. Davis, R. P. Bagozzi, and P. R. Warshaw, "Extrinsic and Intrinsic Motivation to Use Computers in the Workplace," Journal of Applied Social Psychology, vol. 22, pp. 1111-1132, 1992.

[81] S.-C. Ho, W.-Y. Sun, and Y.-M. Wang, "Investigation of Factors Influencing the Adoption of Mobile Data Services," in Proceedings of the 13th International Conference on Electronic Commerce, Liverpool, United Kingdom, 2011, pp. 1-8.

[82] D. H. Haejung Yun, and Choong Lee, , "Extending UTAUT to Predict the Use of Location-Based Services," International Conference on Information Systems (ICIS), 2011.

[83] B. Kargin, N. Basoglu, and T. Daim, "Factors affecting the adoption of mobile services," International Journal of Services Sciences, vol. 2, pp. 29-52, 2009.

[84] C. O. Seneler, N. Basoglu, and T. U. Daim, "A taxonomy for technology adoption: A human computer interaction perspective," in Management of Engineering \& Technology, 2008. PICMET 2008. Portland International Conference on, 2008, pp. 2208-2219.

[85] N. K. Gale, G. Heath, E. Cameron, S. Rashid, and S. Redwood, "Using the framework method for the analysis of qualitative data in multi-disciplinary health research," BMC medical research methodology, vol. 13, p. 117, 2013.

[86] A. McKenna, F. McMartin, Y. Terada, V. Sirivedhin, and A. Agogino, "A Framework for Interpreting Students' Perceptions of an 
Integrated Curriculum," in Proceedings, 2001 ASEE Annual Conference and Exposition, 2001.

[87] P. B. Paulus and V. R. Brown, "Toward More Creative and Innovative Group Idea Generation: A Cognitive-Social-Motivational Perspective of Brainstorming," Social and Personality Psychology Compass, vol. 1, pp. 248-265, 2007.

[88] R. P. McGlynn, D. McGurk, V. S. Effland, N. L. Johll, and D. J. Harding, "Brainstorming and task performance in groups constrained by evidence," Organizational behavior and human decision processes, vol. 93, pp. 75-87, 2004.

[89] H.-C. Wang, D. Cosley, and S. R. Fussell, "Idea Expander: Supporting group brainstorming with conversationally triggered visual thinking stimuli," in Proceedings of the 2010 ACM conference on Computer supported cooperative work, 2010, pp. 103-106.

[90] P. C. Shih, G. Venolia, and G. M. Olson, "Brainstorming under constraints: why software developers brainstorm in groups," in Proceedings of the 25th BCS Conference on Human-Computer Interaction, 2011, pp. 74-83.

[91] J. Ritchie, J. Lewis, C. M. Nicholls, and R. Ormston, Qualitative research practice: A guide for social science students and researchers: Sage, 2013.

[92] L. Chase and J. Alvarez, "Internet research: The role of the focus group," Library \& Information Science Research, vol. 22, pp. 357369,2000 .

[93] W. B. Dodds, K. B. Monroe, and D. Grewal, "Effects of price, brand, and store information on buyers' product evaluations," Journal of Marketing Research (JMR), vol. 28, 1991.

[94] V. Venkatesh, J. Thong, and X. Xu, "Consumer acceptance and use of information technology: extending the unified theory of acceptance and use of technology," MIS quarterly, vol. 36, pp. 157-178, 2012.

[95] H.-W. Kim, H. C. Chan, and S. Gupta, "Value-based adoption of mobile internet: an empirical investigation," Decision Support Systems, vol. 43, pp. 111-126, 2007.

[96] S.-J. Hong, K. Y. Tam, and J. Kim, "Mobile data service fuels the desire for uniqueness," Journal of Communications of the ACM, vol. 49, pp. 89-94, 2006.

[97] C. Je Ho and P. Myeong-Cheol, "Mobile internet acceptance in Korea," Internet Research: Electronic Networking Applications and Policy, vol. 15, pp. 125-40, 2005.
[98] E. J. Arruda-Filho, J. A. Cabusas, and N. Dholakia, "Social behavior and brand devotion among iPhone innovators," International journal of information management, vol. 30, pp. 475-480, 2010.

[99] A. Haywood and G. Boguslawski, "I Love My iPhone... But There Are Certain Things That 'Niggle'Me," in Human-Computer Interaction. New Trends, ed: Springer, 2009, pp. 421-430.

[100] M. M. Rana and U. Rana, "Accessibility evaluation of iPhone's user interface for visually impaired," The proceedings of internet and multimedia systems and applications, pp. 164-167, 2009.

[101] H. Tscherning and L. Mathiassen, The Role of Social Networks in Early Adoption of Mobile Devices: Springer, 2010.

[102] J. West and M. Mace, "Browsing as the killer app: Explaining the rapid success of Apple's iPhone," Telecommunications Policy, vol. 34, pp. 270-286, 2010.

[103] P. Nanda, J. Bos, K.-L. Kramer, C. Hay, and J. Ignacz, "Effect of smartphone aesthetic design on users' emotional reaction: An empirical study," The TQM Journal, vol. 20, pp. 348-355, 2008.

[104] R. W. Belk, "An exploratory assessment of situational effects in buyer behavior," Journal of Marketing Research, pp. 156-163, 1974.

[105] R. W. Belk, "Situational variables and consumer behavior," Journal of Consumer research, pp. 157-164, 1975.

[106] S. Ward and T. S. Robertson, "Consumer behavior research: Promise and prospects," Scott Ward and Thomas S. Robertson, Consumer Behavior: Theoretical Sources. Englewood Cliffs: Prentice-Hall, pp. 3-42, 1973.

[107] R. R. Harmon and G. Laird, "Linking marketing strategy to customer value: implications for technology marketers," in Innovation in Technology Management-The Key to Global Leadership. PICMET'97: Portland International Conference on Management and Technology, 1997, pp. 896-900.

[108] M. Alavi and E. A. Joachimsthaler, "Revisiting DSS implementation research: A meta-analysis of the literature and suggestions for researchers," Mis Quarterly, pp. 95-116, 1992.

[109] M. Fishbein, and I Ajzen, Belief, Attitude, Intention and Behaviour: An Introduction to Theory and Research: Addison-Wesley, 1975. 